Policy brief

\title{
Arctic Freshwater Capital in the Nordic Countries
}

Natural Capital Accounting

(11) Nordic Council of Ministers

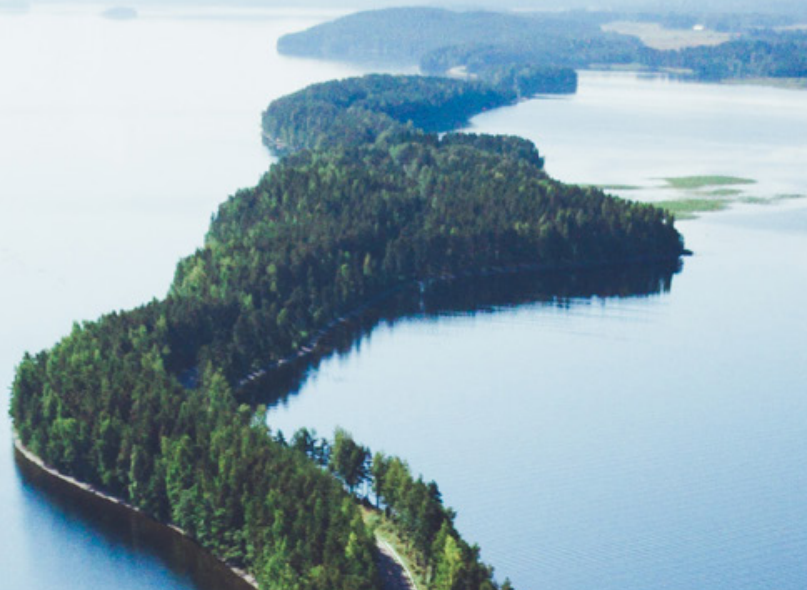


Policy Brief: Arctic Freshwater Capital in the Nordic Countries

Natural Capital Accounting

Authors: Soile Oinonen, Jani Salminen, Johanna Pohjola,

Virpi Lehtoranta, Tuija Mattsson, Sari Väisänen and Luke Dodd.

Jani Laturi (Luke) and Hannu Savolainen (SYKE) are gratefully acknowledged for providing model results.

\section{Nord 2019:004}

ISBN 978-92-893-5995-5 (PRINT)

ISBN 978-92-893-5996-2 (PDF)

ISBN 978-92-893-5997-9 (EPUB)

http://dx.doi.org/10.6027/Nord2019-004

(C) Nordic Council of Ministers 2019

Layout: Jette Koefoed

Cover Photo: Taneli Lahtinen

Print: Rosendahls

Printed in Denmark

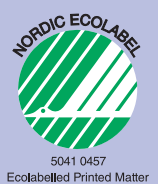

\section{Nordic co-operation}

Nordic co-operation is one of the world's most extensive forms of regional collaboration, involving Denmark, Finland, Iceland, Norway, Sweden, and the Faroe Islands, Greenland, and Åland.

Nordic co-operation has firm traditions in politics, the economy, and culture. It plays an important role in European and international collaboration, and aims at creating a strong Nordic community in a strong Europe.

Nordic co-operation seeks to safeguard Nordic and regional interests and principles in the global community. Common Nordic values help the region solidify its position as one of the world's most innovative and competitive.

\section{Nordic Council of Ministers \\ Nordens Hus \\ Ved Stranden 18 \\ DK-1061 Copenhagen $\mathrm{K}$ \\ www.norden.org}

Download Nordic publications at www.norden.org/nordpub 
Policy brief

\section{Arctic Freshwater Capital in the Nordic Countries}

Natural Capital Accounting

\section{Contents}

Arctic Freshwater Capital in the Nordic 5

Countries Arctic freshwater 7

Natural capital \& ecosystem services $\quad 7$

Construction of water accounts 9

Applications of water accounting $\quad 10$

Example of an economic and

Environmental impact analysis 13

Recommendations $\quad 16$

References 19 
Arctic Freshwater Natural Capital is a flagship project for the Finnish Presidency of the Nordic Council of Ministers. The main themes of the Presidency (2016-2018) are water, nature and people.
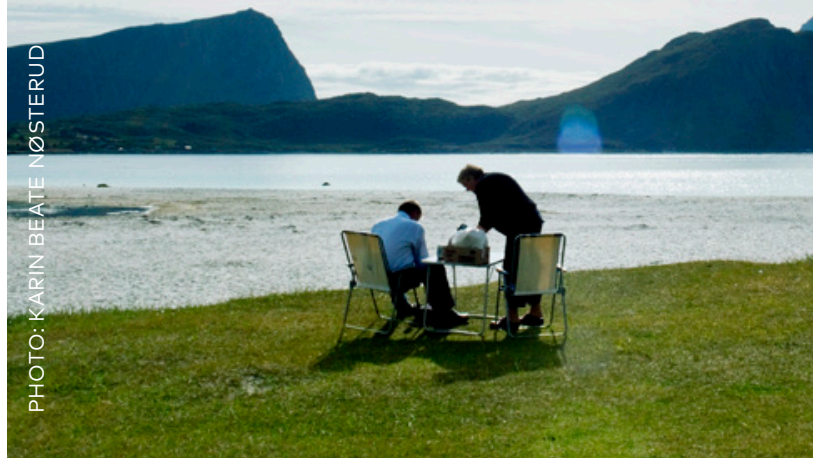


\section{Arctic Freshwater Capital in the Nordic Countries}

Current indicators of economic growth do not adequately consider sustainability, while environmental indicators alone fail to acknowledge the economic needs of a society. For example UN Sustainable Development Goals and EU Biodiversity Strategy call for actions to assess the status and future of ecosystem services and their contribution to the welfare of current and future generations. Arctic Freshwater Natural Capital is a flagship project for the Finnish Presidency of the Nordic Council of Ministers. The main themes of the Presidency (2016-2018) are water, nature and people. The project has addressed all these themes through the lenses of environmental and ecosystem accounting which allows for systematic linking of environment and economy. Using Finnish Lapland as a case-study we demonstrate how existing environmental monitoring data can be combined with economic data following international statistical standards, and how this is used as an input to forward looking models to assess economic, societal and environmental impacts of economic investments like pulp mills or environmental investments like nature protection. This report summarizes the findings published in Arctic Freshwater Natural Capital in the Nordic Countries; more discussion of the topics in this policy brief can be found in the full report at www.norden.org. 


\section{ARCTIC FRESHWATER}

Freshwater resources are essential for all human societies and economies, yet they are often taken for granted in the Northern/Arctic regions. However, dramatic changes are occurring in the region due to various global and regional drivers such as climate change and increased use of natural resources that will affect freshwaters. The increasing precipitation and temperature brought on by climate change is a particularly important driver altering the hydrology of the Arctic; modifying the presence and flow of freshwater through the region's lakes, rivers and wetlands. In the Arctic, warming is estimated to be two to three times higher than the global annual average (IPCC 2018). As the Arctic gets warmer; changing weather patterns and hydrology; it also becomes easier to exploit its natural resources, placing even greater pressure on freshwater ecosystems (Prowse et al. 2015).

The need for systematic analysis of economy-environment interactions has never been so urgent.

\section{NATURAL CAPITAL \& ECOSYSTEM SERVICES}

Natural capital refers to both renewable resources, like water and forests, and non-renewables, like oil and minerals. It can also take intangible forms, for example as information stored in species and ecosystems.

While natural capital provides a reference to stocks, ecosystem services denote the flow of benefits from these stocks to society. Arctic freshwater systems provide a wide range of important ecosystem services, including support for biodiversity, habitat for commercial and subsistence species, drinking water, transport, and recreation. Indirectly, they also affect a wide variety of functions including carbon sequestration, Arctic Ocean acidity levels, and broader hydrological cycles.

Eventually, the intensity and continuity of ecosystem service flows are subject to the condition of the natural capital of interest. In most cases, trade-offs are inevitable where the flow of a selection of services may be augmented while the others may decline. Because of the difference between stocks and ecosystem service flows, the concept of natural capital is an important framework for joining stocks and service flows together. 


\section{Figure 1: Natural capital \& ecosystem services}

\section{Natural Capital}

are stocks of natural assets that can be used as inputs for economic production. Examples include pollinating insects, wetlands, and standing timber (illustrated below).
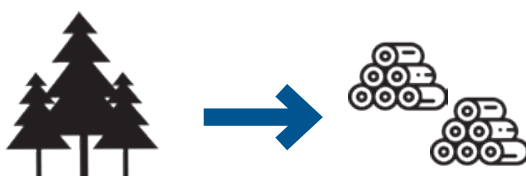

\section{Natural Capital Accounting (NCA)}

provides an explicit picture of the relationship between economic development and the state of natural assets. It demonstrates the consequences of a country's economic growth on the exploitation of its natural resources. The overall goal of NCA is to account not only what is recorded in market activities (e.g. timber production) but also capital not reflected in market transactions (e.g. water purification) It does this by integrating accounts for stocks of natural resources and pollutants with asset and flow accounts for ecosystem services.

\section{System for Environmental and Economic Accounts - Water}

System for Environmental and Economic Accounts (SEEA)

is the internationally recognized standard approach to NCA. It consists of two frameworks; SEEA Central Framework (SEEA-CF, adopted in 2012) and SEEA Experimental Ecosystem Accounting (SEEA-EEA, adopted in 2013). When integrated into the System of National Accounts (SNA) (below), SEEA accounts bring into direct focus the relationship between the environment and well-being not revealed through traditional measures of economic activity, such as GDP.

\section{$\begin{array}{lll}\mathbf{b} & \square\end{array}$}

In water accounting, the flows of water from the environment to the economy, within the economy, and back to the environment, are documented. Water use accounts track use across sources, regions, and sectors/industries, while water return flow and emission accounts help to understand how different sectors/industries contribute to water pollution. 


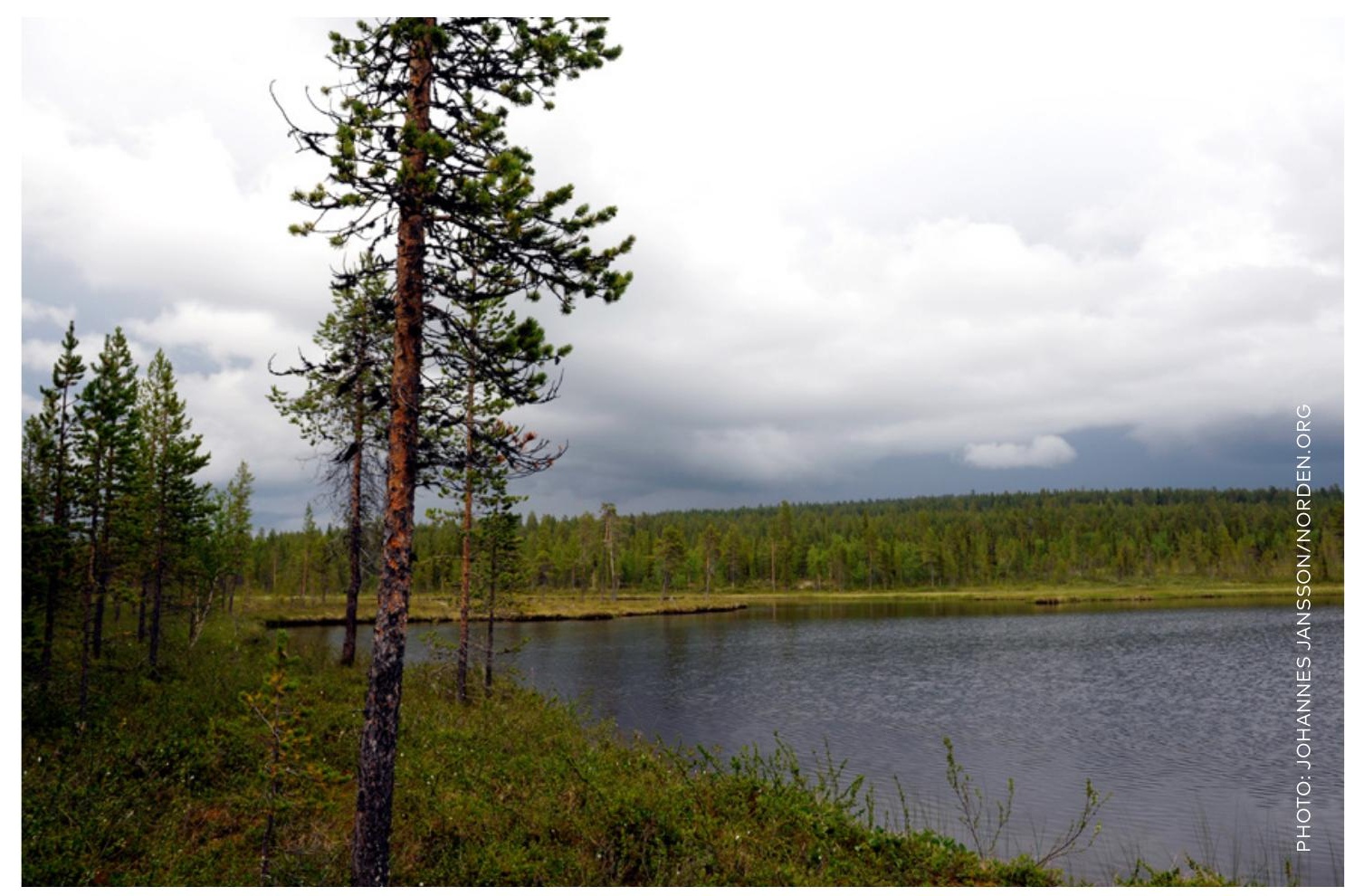

\section{CONSTRUCTION OF WATER ACCOUNTS}

Construction of regional water use and emission accounts for Finnish Lapland begins by constructing national water accounts dissagregated across hundreds of different industries. Data are compiled or extrapolated from existing sources in a highly labor intensive process but the accounting concept and the data provided by it can then be used for many applications. As yet, this phase cannot be automated. From the national accounts, water utilization coefficients can be calculated for each industry and then multiplied with the industry's regional activity to estimate regional water utilization. For instance, national water use volume $\left(\mathrm{m}^{3} / \mathrm{a}\right)$ in the paper and pulp industry is divided by total national revenue $(€)$ of that industry and then multiplied with industry revenue from Finnish Lapland during the same period. The generated water use volume estimate can then be used in the regional water account. This method can also be applied to create accounts for any geographic areas of interest, for instance, river basin district accounts to respond to the requirements of the Water Framework Directive. 


\section{APPLICATIONS OF WATER ACCOUNTING}

The value of sophisticated water accounts lies in their many applications. Waste water and emission accounts are of great value for efficiency assessments of water protection measures. Regional water accounts can be compared with the water assets in that region to assess the sustainability of the use of water resources. Natural capital accounting could be a useful aid in policy evaluation. It provides a uniform way to present the outcomes of alternative policy scenarios. Water-amended input-output modelling allows interesting opportunities e.g. for studying water issues in the contexts of circular economy and international trade (figure 4).
Water accounting also enables the investigation of the use of water and generation of water emissions along the entire life cycle of a commodity. This includes both direct impacts and indirect impacts resulting from the use of intermediary products and services along the production and consumption chains. This generates a holistic understanding of the environmental-economic impacts of different products and services. One such holistic "foot print" is illustrated in figure 2 for milk.

Figure 2: Water use \& emissions to water along production and consumption chains

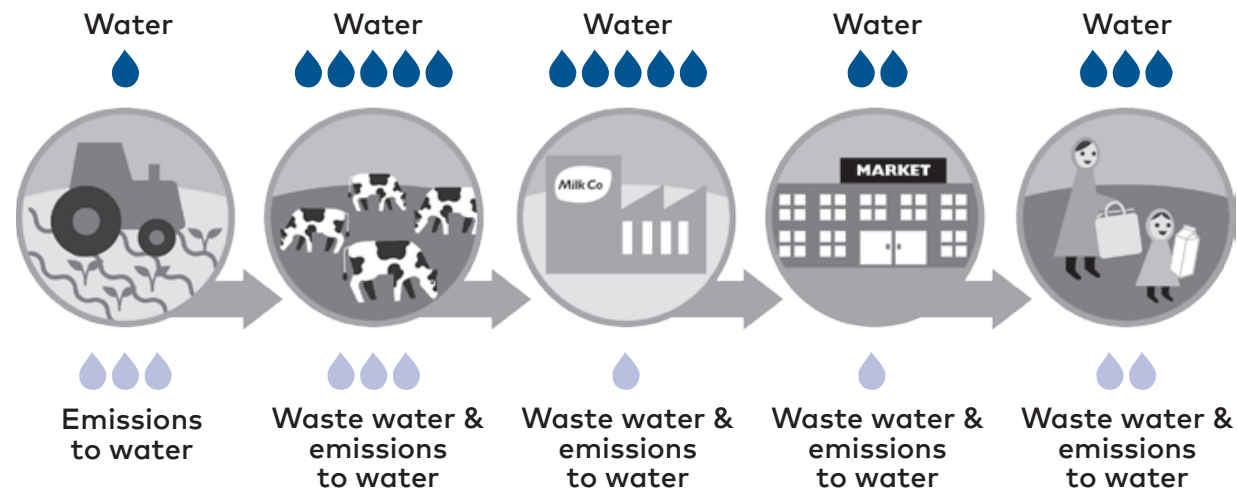


These data can also be used to assess water related impacts of potential changes in economic activity. Industryspecific water emission characteristics and industry intensity in a geographic area of interest can be combined with surface water quality maps to determine industry level impacts on water quality (figure 3; table 1). These data can be formulated for current conditions or to reflect a proposed change in economic activity. Explicitly linking economic sectors, their emissions and water quality is the key for designing costefficient management measures. As the effect of such measures cascades from river and lakes finally out to the seas, such tools are valuable in designing economically and ecologically sound policies for the EU Water and Marine Framework Strategies.

\section{Figure 3: Ecological status}

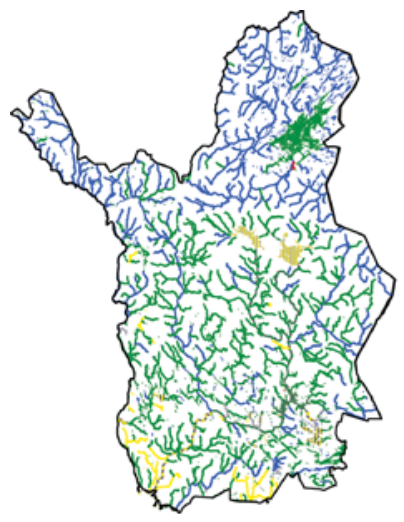

Excellent

Good

Satisfactory

Passable

Poor

Classification is based on data @ SYKE, Luke, ELY centres, MML from 2006-2012

Table 1: Economic and water-related data on a sample of relevant industries in the Finnish Lapland

\begin{tabular}{|l|l|l|l|l|}
\hline Industry & Employees & $\begin{array}{l}\text { Share of } \\
\text { Lapland (\%) }\end{array}$ & $\begin{array}{l}\text { Water } \\
\text { intensity }\end{array}$ & $\begin{array}{l}\text { Industry-specific examples of } \\
\text { typical waste water components }\end{array}$ \\
\hline Basic iron, steel \% ferro-alloys & 2466 & 60 & Very high & Heat, metals \\
\hline Accomodation & 1380 & 11 & High & Nutrients \\
\hline Pulp, paper and paperboard & 1200 & 10 & Very high & Nutrients, organic carbon \\
\hline Mining or ore metals & 543 & 19 & High & Metals, sulphate \\
\hline Motor vehicles & 301 & 26 & Moderate & - \\
\hline Skiing centres & 180 & 15 & High & Nutrients,consumer chemicals \\
\hline Freshwater aquaculture & 33 & 15 & Very high & Nutrients \\
\hline All industries & 30630 & 2.6 & - & Not applicable \\
\hline
\end{tabular}

\footnotetext{
${ }^{1}$ Percent of the industy's total revenue in Finland
} 


\section{Figure 4: Uses of water accounts}

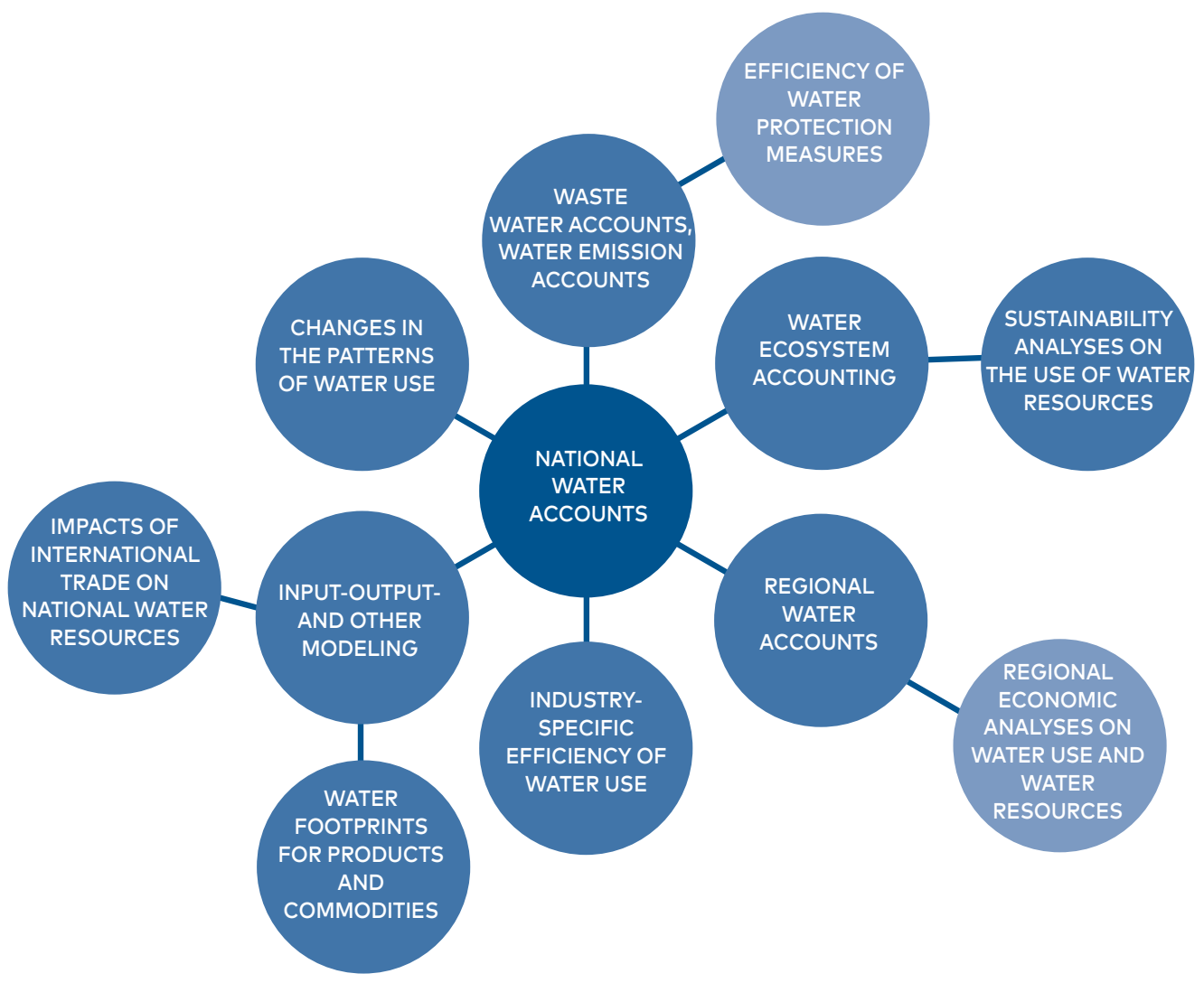




\section{EXAMPLE OF AN ECONOMIC AND ENVIRONMENTAL IMPACT ANALYSIS}

Natural Capital Accounting (NCA) is used to record the current status and past development of the economy or environment. It can also be used in forward-looking policy and scenario analyses to assess environmental, economic and social impacts. In this impact analysis, we focus on changes in water use and the trade-offs between wood production and carbon sequestration in the case of establishing a new pulp mill in the Finnish Lapland. This example has been chosen because forest industry is among the most important users of freshwater resource, forests are an important ecosystem in Lapland and the mitigation of climate change is one of the most important issues for Arctic region. Results are obtained from forest sector model FinFEP (Lintunen et al. 2015) and the economy-wide, environmentallyextended input-output model ENVIMAT1O (Seppälä et al. 2011).

\section{Pulp mill effect on water use}

The hypothetical investment in pulp production increases direct freshwater use by roughly 26 million $\mathrm{m}^{3}$ nationally ( $8 \%$ increase), primarily in the paper and pulp industry (the new pulp mill's direct use) and energy production sector. It also increases indirect water use throughout the economy. Indirect water use refers to water volumes that are needed in the making of intermediary products. In our example, indirect water use generated by the hypothetical pulp investment was on the same order of magnitude for many industries but up to 1000 times higher for others. This demonstrates the importance of considering and estimating environmental impacts along entire chains of production (footprints) using tools like wateramended input-output modelling in the very same manner in which the impacts on labour and value added are estimated.

\section{Pulp mill effect on forest asset and supplies of ecosystem services - monetary units}

In our example, the forest asset consists of two ecosystem services: timber production as provisioning service; carbon sequestration as regulating service. Values of ecosystem services are calculated as net present values reflecting the value over time. Timber prices are market prices based on forest statistics and harvesting costs are based on real cost data. For carbon there is no unambiguous value. We have based our values on the emission trading market, with the lower carbon price close to the average price of the EU emission allowance in 2018 and the higher price still far below the estimated price needed to stabilize the global temperature increase below $2^{\circ} \mathrm{C}$ (IPCC 2018). 
Table 2 presents how a new pulp mill affects the net present values of forest asset, timber production and carbon sink in Lapland. The value of timber production increases due to both higher level of cuttings and higher timber prices caused by the increased demand. Contrastingly, increasing cuttings decreases the carbon sink thus decreasing the value of carbon sink. This illustrates the trade-off between timber production and carbon sink. The impact of a new pulp mill on the value of forest asset is highly dependent on the price used for carbon. With a carbon price of $15 € / t \mathrm{CO}_{2}$, the value of forest asset increases by 85 million euros in Lapland. For a carbon price of $30 € / \mathrm{t} \mathrm{CO}$, the impact on total asset value is the opposite with a decrease of 140 million euros.

The trade-off between timber production and carbon sink is clearly also seen in the annual supplies of these ecosystem services within Lapland (figure 5). Interestingly, trade-offs does not appear in all periods, as seen in the case of 25 years after production begins. This is due to the age structure of the forest. The figure illustrates that the impacts of economic actions like investments or policies may not be constant over time.

\section{Trade-offs between the environment and economy}

In many cases, values for ecosystem services are not available or are not reliable. It is however possible to present economic and environmental impacts and illustrate trade-offs in physical or other non-monetary units. Table 3 does this for the new pulp mill scenario; the numbers presented are for the whole of Finland. The economic benefits of the new pulp mill include increased amount of pulp produced and improved employment. However, additional production increases the use of freshwater and standing forests, increasing pollution loading to the water and decreasing the amount of carbon sink provided by the forest.

CAPITAL project has demonstrated that water accounting can provide accurate and reliable data and holistic understanding of the relations between economies and the environment. In today's world, humankind faces multiple environmental problems that need simultaneous action. Environmentaleconomic accounting provides an invaluable tool for attempts to balance current and future well being as it provides a platform for analysing multiple factors simultaneously including, economic growth, water use and emissions, greenhouse gas emissions, energy consumption, waste generation and land use. Environmental-economic accounting is also based on international standards making it valuable at scales from local to international. 
Table 2: Economic units

\section{Economic units}

Carbon sink

Timber production

Total asset value
Carbon price $15 € / \mathrm{t} \mathrm{CO} 2$

Carbon price $30 € / \mathrm{t} \mathrm{CO}_{2}$

Carbon price $15 € / \mathrm{t} \mathrm{CO}_{2}$

Carbon price $30 € / \mathrm{t} \mathrm{CO}_{2}$
$-225 \mathrm{M} €$

$-450 \mathrm{M} €$

$310 \mathrm{M€}$

$85 \mathrm{M} €$

$-140 \mathrm{M} €$

Table 3: Physical units

\section{Physical units}

Pulp, tonnes

$+400,000.0$

Employment, persons

Total

$+1,700.0$

Forest sector

$+600.0$

Harvests, million $\mathrm{m}^{3}$

$+2.0$

Use of freshwater, million $\mathrm{m}^{3}$

$+26.2$

Carbon sink, million ${\mathrm{t} \mathrm{CO}_{2}}$

$-3.0$

Figure 5: Annual value of the supply of two ecosystem services and net forest asset value within Finnish Lapland

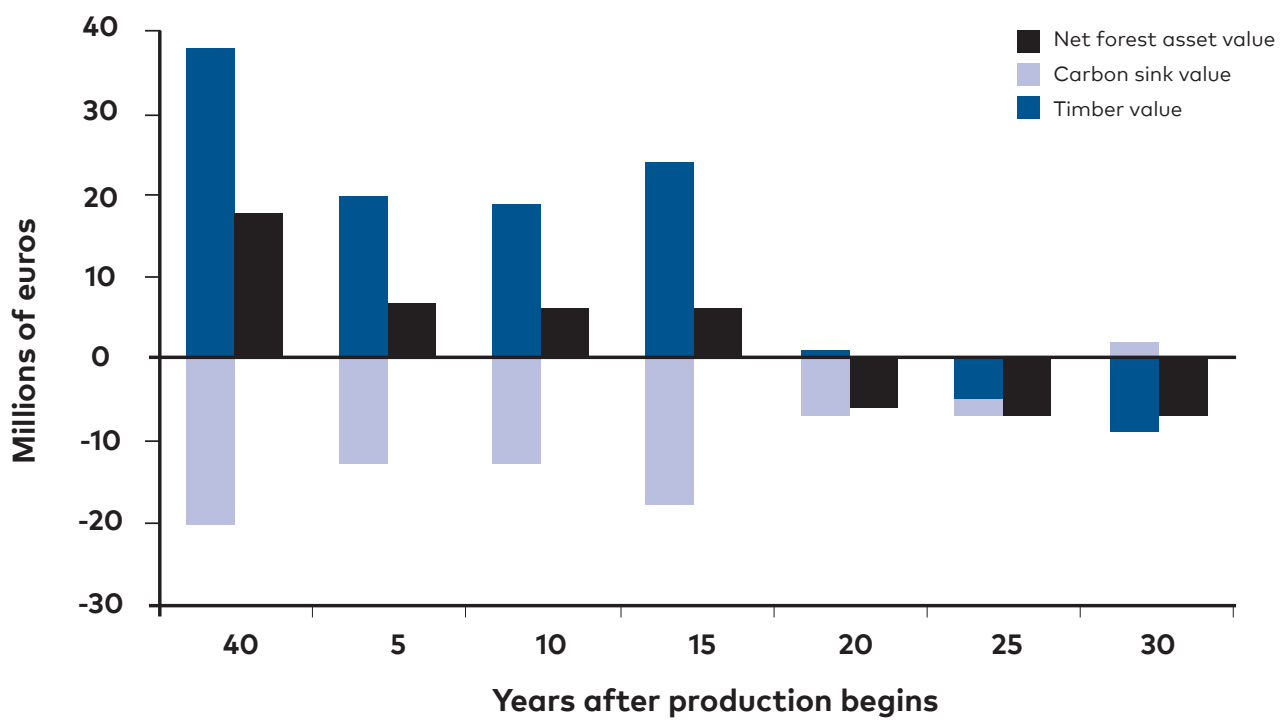




\section{RECOMMENDATIONS}

The Nordic countries have a long

experience with environmental

accounting - this tradition exists, we

should take most out of it. Opportunities

exist to further develop and deploy

environmental accounting in current

EU frameworks. For instance, both the

Water Framework Directive (WFD)

and Marine Strategy Framework

Directive (MSFD) require member

states to provide economic anlyses of

the uses and proposed policy measures

impacting goverend areas (WFD,

Article 5; MSFD, Articles 8 \&13). The

WFD also requires full cost recovery of water use and emissions (Article 9).

Both of these tasks can be supported

by economic accounting of freshwater

resources. Similar opportunities

exist for implementation or data

generation in the Habitat Directive,

Birds Directive, Biodiversity Strategy,

Sustainable Development Goals \&

Agenda 2030, reporting to the European

Environmental Agency (WISE SoE),

national \& regional planning, and many

more.
However, recent interviews with statisticians and water framework directive experts show that at the moment environmental accounting data is of no practical value in the real planning or decision making level for many of these policies. Nordic water management experts are not familiar with the accounts or are unable to link them to the implementation of the Directives. Adapting existing institutional structures or the creation of new structures will be crucial to the long term success of the WFD and fully realizing the value of water accounting in this context. 
We propose 6 areas of action to continue the development and deployment of environmental accounting.

Educate environmental scientists and environmental economists on environmental and ecosystem accounting statistical standards and frameworks.

2 Test the existing data sets resulting from environmental valuation studies in an accounting framework.

3 Engage WFD, MSFD and Biodiversity policy experts to determine how they could contribute in the development of ecosystem accounts and provide information on how they could apply the accounts to give informed policy advice.

4 Allocate resources for the development of environmental and ecosystem accounts and their regular update e.g. in every 5 years.

5 Use accounting information to develop indicators for Sustainable Development Goals.

6 Integrate environmental and economic accounts with economic models to analyze the impact of investments and policies. 


\section{References}

IPCC. 2018. Special Report on Global

Warming of $1.5^{\circ} \mathrm{C}$. SR 15 .

Lintunen, J., J. Laturi, and J. Uusivuori. 2015.

Finnish Forest and Energy Policy Model

(FinFEP): A model description. Natural

resources and bioeconomy studies 59/2015,

Luke.

Prowse, T., A. Bring, J. Mard, and E.

Carmack. 2015. Arctic freshwater synthesis:

Introduction. Journal of Geophysical

Research-Biogeosciences 120:2121-2131.

Seppälä, J., I. Mäenpää, S. Koskela, T. Mattila, A. Nissinen, J.-M. Katajajuuri, T. Härmä, M.-R. Korhonen, M. Saarinen, and Y. Virtanen. 2011. An assessment of greenhouse gas emissions and material flows caused by the Finnish economy using the ENVIMAT model. Journal of Cleaner Production 19:1833-1841. 
$\mathbb{1}$

Nordic Council of Ministers

Nordens Hus

Ved Stranden 18

DK-1061 Copenhagen K

www.norden.org

\section{Policy Brief: Arctic Freshwater Capital in the Nordic Countries}

Current indicators of economic growth (e.g., GDP) do not adequately consider sustainability, while environmental indicators alone fail to acknowledge the economic needs of a society. Natural Capital Accounting (NCA) can be the tool that fills the gap separating current economic and environmental indicators but development and adoption remains uneven across the Nordic region. This policy brief provides background on NCA and its associated accounting frameworks, demonstrates the applicability of NCA for sustainably utilizing freshwater resources in the Nordic Arctic and provides recommendations for maximizing the value of environmental accounting as an economic, environmental, and sustainable development tool. 